\title{
Mathematical Problem Solving Capabilities: Self- Confidence, Self-Efficacy, Emotional Intelligence, and Concept Understanding Ability
}

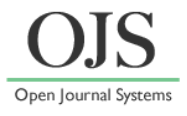

\author{
Syaipul Amri ${ }^{*}$, Wahyu Widada ${ }^{2}$, Agus Susanta ${ }^{2}$ Zamzaili $^{2}$ \\ ${ }^{1}$ Doctor of Education Program, University of Bengkulu \\ ${ }^{2}$ Master Program of Mathematics Education, University of Bengkulu \\ *Email: amrisyaipuldiknas@gmail.com
}

DOI: https://doi.org/10.33369/pendipa.4.3.20-26

\begin{abstract}
Mathematics is a compulsory subject in all of Indonesian high school. Problem solving ability is a competency that must be possessed in learning mathematics. The purpose of this study was to examine the variables that affect the ability to solve mathematical problems. These variables are self confidence, self efficacy, emotional intelligence, and the ability to understand concepts. This is a survey research, with a sample of 100 people. The sample was selected by simple random technique from all high school students in Bengkulu City. There are five instruments of this research, namely a test of mathematical problem-solving ability, a concept comprehension ability test, and three questionnaires for self confidence, self efficacy, as well as an emotional intelligence questionnaire. Research data were analyzed through path analysis using SPSS and the Lisrel Application Program. The results of this study were the variables of self confidence, self efficacy, emotional intelligence, and the ability to understand concepts have a direct positive effect on the ability to solve mathematical problems. From this research, we conclude that the ability to solve mathematical problems through self-confidence, self-efficacy, emotional intelligence, and the ability to understand concepts students were in a good category.
\end{abstract}

Keywords: Problem solving ability, self-confidence, self-efficacy, emotional intelligence, the ability to understand concepts.

\section{INTRODUCTION}

Efforts to improve mathematical abilities continue to be made, but the results of national mathematics exams are low. One of the students' difficulties is solving mathematical problems. That is a musthave ability in learning mathematics. Problem solving ability is one part of learning mathematics. Problem solving is an important component of comprehensive 21st century education (Amri \& Widada, 2019). According to (Wismath, Orr, Zhong, Wismath, \& Program, 2014), that Problem solving is also an activity that must be had in daily life. Students need to understand the problem, translate in mathematical language, and solve it mathematically, finally he can find a solution to the problem. They tend to have difficulty making mathematical models, and often forget not to translate mathematical solutions to actual problems (Nugroho, Widada, \& Herawaty, 2019; D. Herawaty, Widada, Novita, Waroka, \& Lubis, 2018; W. Widada, Herawaty, \&
Lubis, 2018). Therefore, problem solving must become a concern for mathematics teachers. Students must be trained to solve problems.

In learning mathematics students can complete various practical tasks and real-life problems. Students can use it in many areas of life. They will remember facts, concepts, principles and skills easily when they use them to solve real problems. Also, students use mathematics to solve real-life problems (Peranginangina \& Surya, 2017). Mathematics teachers must always try to emphasize the interrelated competencies given in mathematics classes. That is to develop problem solving skills in students who will help them in solving everyday problems and maintain sustainable development in the 21 st century (Akinmola, 2014). Therefore, the right teaching strategy is needed. Common explicit problem solving teaching strategies and guided inquiry have comparable effectiveness in teaching problem solving (Mataka, Cobern, Grunert, 
Mutambuki, \& Akom, 2014). In learning mathematics problem solving, mathematical objects become content that is a prerequisite for students. These objects are facts, concepts, principles and operations (W. Widada \& Herawaty, 2017). This means that the ability to understand concepts is one of the variables students must have to be able to solve mathematical problems. Concepts are abstract ideas that can be used to classify objects as examples or not examples of these concepts. Therefore students who understand the concept are able to explain with various real examples and are able to show the position of the concept in the deductive structure of mathematics (Dewi Herawaty, Widada, Herdian, \& Nugroho, 2020; Dewi Herawaty, Widada, Handayani, Febrianti, \& Abdurrobbil, 2020). That is a process of learning realistic mathematics with ethnomathematics approach can be a vehicle for students to simplify the concept of function to be more meaningful (Dewi Herawaty, Widada, Adhitya, Sari, \& Novianita, 2020).

Research result Surya, Putri, \& Mukhtar (2017) states Increased mathematical problem solving abilities of students taught with contextual learning models are higher than students taught with expository learning. Increased selfconfidence of students who are taught with contextual learning models is higher than students who are taught with expository learning. There is an interaction between the learning model with the students 'initial mathematical ability to improve students' mathematical problem-solving abilities. There is an interaction between learning models with students' initial mathematical abilities to increase student self-confidence. This study states that self-confidence affects the ability to solve mathematical problems.

Findings from a study suggest that although women feel less self-efficacy in problem solving than men, they have a better chance of increasing perceived self-efficacy than men. These differences found between men and women regarding their perceptions of self-efficacy show that when designing any type of educational intervention aimed at improving self-efficacy, the sex of the individual must be taken into account (Flores, Mayorga-Vega, Blanco, \& Blanco, 2014). The results of this study signal that self-efficacy has an influence on the ability of problem solving.
Self-efficacy and problem solving are direct and indirect predictors of mental health. The relationship between self-efficacy and problem solving with mental health is very strong. Evidence for mediation mechanisms through which assertiveness mediates the relationship between self-efficacy and problem solving with mental health (Parto, 2011). This gives a sign that self-efficacy and problem solving are two related variables.

There is a relationship between the components of emotional intelligence and problem solving (Biswas \& Ferdausy, 2017). They stated that the component of emotional intelligence was found to be positively correlated with problem solving. We must develop emotional intelligence that can make a valuable contribution to finding the right solution for a problem.

Based on the study, it states that the ability to solve mathematical problems is influenced by self-confidence, self-efficacy, emotional intelligence, and the ability to understand concepts. The ability to solve mathematical problems is a crucial component in learning mathematics. According to (Akinmola, 2014), that mathematics is an excellent vehicle for developing one's intellectual competence in logical reasoning, spatial visualization, analysis and abstract thinking. Students develop the ability to count, reason, think and solve problems through learning and applying mathematics. This is assessed not only in science and technology but also in everyday life and at work. Thus, we are interested in examining the causal relationship between self-confidence, self-efficacy, emotional intelligence, and the ability to understand concepts, and the ability to solve mathematical problems.

\section{RESEARCH METHODS}

Research is a survey research with a quantitative approach. Information was obtained from samples collected directly at the scene empirically, with the aim of finding out the opinions of the sample objects being studied. The population of this study were all high school final year students in Bengkulu City, totaling 3,855 
students. Samples were selected by a simple random sampling technique of 100 people. Data collection used five research instruments, namely self-confidence questionnaire, adopting selfefficacy, emotional intelligence questionnaire, and the ability to understand concept tests, and tests of mathematical problem-solving abilities. The five instruments have been tested for validity and reliability in the very high category. Data were analyzed using path analysis. For this purpose, we use the Lisrel 8.8 application.

\section{RESULTS AND DISCUSSION}

This research data includes five construct variables namely X1 = Self Confidence $(\mathrm{SC}) \mathrm{X} 2$ $=$ Self Efficacy (SE), X3 = Emotional Intelligence (KE), X4 = Mathematical Concept Understanding Ability (KPK), and Y = Mathematical ProblemSolving Ability (KPMM). Data were analyzed using inferential statistics. For this reason, we first conduct a prerequisite test. The normality of estimated errors through the Lilliefors test is the difference between the theoretical frequency and the real frequency at each error value. The maximum absolute price of the difference is what we call Lo. Based on the estimated error normality test the following results are obtained:

1. The estimated error distribution of the mathematical problem-solving ability of self-confidence ( $\mathrm{Y}$ over X1) obtained Lcount statistic $=0.0824$, this value is smaller than the L-table $=(\mathrm{n}=100 ; \alpha=$ $0.05)=0,0886$. That means that the Y error data for X1 comes from normally distributed data.

2. As the previous statistical count, then successively obtained results:

a. Distribution of error estimation of mathematical problem-solving ability for self-efficacy ( $\mathrm{Y}$ over $\mathrm{X} 2$ ), with $\mathrm{L}=$ $(0.08531)<$ Ltable $=(0.0886)$, means that the Y error data for $\mathrm{X} 2$ comes from normal distribution data.

b. The error distribution of the estimated mathematical problem-solving ability over the ability to understand mathematical concepts ( $\mathrm{Y}$ over X4), with $\mathrm{L}=(0.0489)<$ Ltable $=(0.0886)$, means that the $\mathrm{Y}$ error data for $\mathrm{X} 4$ comes from normal distribution data. c. Error distribution estimated ability to understand mathematical concepts of self-confidence $(\mathrm{X} 4$ over $\mathrm{X} 1)$, with $\mathrm{L}=$ $(0.08240)<$ Ltable $=(0.0886)$, means that the error data $\mathrm{X} 4$ against $\mathrm{X} 1$ comes from normal distribution data.

d. Error distribution estimated ability to understand mathematical concepts over Self Efficacy (X4 over X2), with L = $(0.0853)<$ Ltable $=(0.0886)$, means that the error data $\mathrm{X} 4$ against $\mathrm{X} 2$ comes from normal distribution data.

e. Distribution of estimated emotional intelligence errors on the ability to understand mathematical concepts (X4 over X3), with $\mathrm{L}=(0.0777)<$ Ltable $=$ (0.0886), means that the error data $\mathrm{X} 4$ against $\mathrm{X} 3$ comes from normal distribution data.

f. Error distribution of estimated emotional intelligence for selfconfidence (X3 over $\mathrm{X} 1)$, with $\mathrm{L}=$ $(0.0824)<$ Ltable $=(0.0886)$, means that the error data X3 against X2 comes from normal distribution data.

g. The error distribution of estimated emotional intelligence for self-efficacy (X3 over X2), with $\mathrm{L}=(0.0853)<$ Ltable $=(0.0886)$, means that the $\mathrm{Y}$ error data against X2 comes from normally distributed data.

h. Distribution of estimated errors of selfefficacy over self-confidence (X2 over $\mathrm{X} 1)$, with $\mathrm{L}=(0.0824)<$ Ltable $=$ (0.0886), means that the Y error data for $\mathrm{X} 2$ comes from normally distributed data.

Based on the analysis of estimated errors, everything comes from normally distributed data. That shows that the first prerequisite test was fulfilled.

The next prerequisite test is the linearity and significance of the regression coefficients. The test is intended to find out how much the equation of the regression line connecting the variables with the dependent variable. Data linearity test uses the F test.

In accordance with the linearity analysis and the significance of the previous regression 
coefficient, successively the results of the other analyzes are presented as follows.

Test the linearity of solving mathematical problems for self-confidence ( $\mathrm{Y}$ over $\mathrm{X} 1$ ), the results of the regression equation $\mathrm{Y}=48.883+$ $0.0955 \mathrm{X} 1$. Based on statistical calculations, obtained $\mathrm{F}=3.961$ with a real level $\alpha=0.05$ and $\mathrm{dk}(1: 98)$ Ftable $=3.938$. Because $F>$ Ftable, the regression is very significant. Linearity test obtained $\mathrm{F}=1.029$, while at the real level $=\alpha=$ 0.05 and $\mathrm{dk}(30 ; 68)$ obtained Ftable $=1.627$ then $\mathrm{F}<$ Ftable so that the linear model can be accepted.

In accordance with the linearity analysis and the significance of the previous regression coefficient, successively the results of the other analyzes are presented as follows.

(a) Test the linearity of mathematical problem solving for self-efficacy (Y over X2) obtained a regression equation $=44.809+$ $0.129 \mathrm{X} 2 . \mathrm{F}=11.796$, and the real level $\alpha=$ 0.05 and $\mathrm{dk}(1 ; 98)$ obtained Ftable $=3.938$. $\mathrm{F}>$ Ftable, the regression is very significant. Linearity test from the calculation results obtained $\mathrm{F}=0.789$, while at the real level $\alpha$ $=0.05$ and $\mathrm{dk}(30: 68)$ obtained Ftable $=$ 1.988 then $\mathrm{F}<$ Ftable so that the regression model is linear.

(b) Analogous to (a), the regression equation = $48.0956+0.1769 \mathrm{X} 4$ is obtained; regression equation $\mathrm{X} 4=29,349+0,335 \mathrm{X} 1$; regression equation $\mathrm{X} 4=29,349+0,335 \mathrm{X} 2$, regression equation $\mathrm{X} 4=16,150+0,527 \mathrm{X} 3$; regression equation $\mathrm{X} 3=72.597+0.244 \mathrm{X} 1$; Regression equation $\mathrm{X} 3=80,471+0,179 \mathrm{X} 2$. Based on statistical tests that all values of $F>$ Ftable at the real level $(\alpha=0.05)$. That means that all of these regression models have very significant coefficient values and form a linear regression.

The prerequisite tests were fulfilled, followed by testing the causality model through path analysis. We use MS assistance. Excel Windows 8, SPSS version program. 22 and Lisrel Application Version 8.8. The results of the analysis of research data can be presented in Table 1.
Table 1. Summary of Path Analysis

\begin{tabular}{lrrrrrl}
\hline \multicolumn{1}{c}{ Causal } & \multicolumn{1}{c}{ F } & F table & T & T table & \multicolumn{1}{c}{ Sig } & Justification \\
\hline X1-Y & 3.961 & 3.940 & 1.990 & 1.980 & 0.049 & There is a direct effect \\
X2-Y & 11.796 & 3.940 & 3.343 & 1.980 & 0.011 & There is a direct effect \\
X4-Y & 6.640 & 3.940 & 2.577 & 1.980 & 0.000 & There is a direct effect \\
X1-X2 & 13.66 & 3.940 & 3.696 & 1.980 & 0.000 & There is a direct effect \\
X1-X3 & 13.05 & 3.940 & 3.610 & 1.980 & 0.000 & There is a direct effect \\
X2-X3 & 10.40 & 3.940 & 3.225 & 1.980 & 0.002 & There is a direct effect \\
X3-X4 & 41.09 & 3.940 & 6.410 & 1.980 & 0.000 & There is a direct effect \\
X2-X4 & 27.94 & 3.940 & 5.280 & 1.980 & 0.000 & There is a direct effect \\
X1-X4 & 30.18 & 3.940 & 5.490 & 1.980 & 0.000 & There is a direct effect \\
\hline
\end{tabular}

Table 1 shows the results of the analysis of the significance of the path coefficients between construct variables. These variables are $\mathrm{X} 1=$ Self Confidence (SC) X2 = Self Efficacy (SE), X3 = Emotional Intelligence (KE), X4 = Mathematical Concept Understanding Ability (KPK), and $\mathrm{Y}=$ Mathematical Problem-Solving Ability (KPMM).

Based on Table 1, there are nine significant direct effects between variables. First, there is a direct influence of $\mathrm{X} 1$ on $\mathrm{Y}$ with $\mathrm{F}=3,961>3,940$ $=\mathrm{F}$ table, with $\mathrm{T}=1,990>1,980=\mathrm{T}$ Table for sig. $=0.049$. There is a direct effect of $\mathrm{X} 2$ on $\mathrm{Y}$ with $\mathrm{F}=11,796>3,940=\mathrm{F}$ table, with $\mathrm{T}=3,343>$ $1,980=\mathrm{T}$ Table for sig. $=0.011$. There is a direct influence of $\mathrm{X} 4$ on $\mathrm{Y}$ with $\mathrm{F}=6,640>3,940=\mathrm{F}$ table, with $\mathrm{T}=2,577>1,980=\mathrm{T}$ Table for sig. $=$ 0,000 . There is a direct effect of $\mathrm{X} 1$ on $\mathrm{X} 2$ with $\mathrm{F}$ $=13.66>3,940=\mathrm{F}$ table, with $\mathrm{T}=3,696>1,980$ $=\mathrm{T}$ Table for sig. $=0,000$. There is a direct effect of $\mathrm{X} 1$ on X3 with $\mathrm{F}=13.05>3,940=\mathrm{F}$ table, with $\mathrm{T}=3,610>1,980=\mathrm{T}$ Table for sig. $=0,000$. There is a direct effect of $\mathrm{X} 2$ on $\mathrm{X} 3$ with $\mathrm{F}=10.40$ > $3,940=\mathrm{F}$ table, with $\mathrm{T}=3,225>1,980=\mathrm{T}$ Table for sig. $=0.002$. There is a direct influence of $\mathrm{X} 3$ on $\mathrm{X} 4$ with $\mathrm{F}=41.09>3,940=\mathrm{F}$ table, with $\mathrm{T}=$ $6,410>1,980=\mathrm{T}$ Table for sig. $=0,000$. There is a direct influence of $\mathrm{X} 2$ on $\mathrm{X} 4$ with $\mathrm{F}=27.94>$ $3,940=\mathrm{F}$ table, with $\mathrm{T}=5,280>1,980=\mathrm{T}$ Table for sig. $=0,000$. There is a direct effect of $\mathrm{X} 1$ on $\mathrm{X} 4$ with $\mathrm{F}=30.18>3,940=\mathrm{F}$ table, with $\mathrm{T}=$ $5,490>1,980=\mathrm{T}$ Table for sig. $=0,000$. These results can be drawn in a complete path diagram based on a statistical test using Lisrel, see Figure 1. 


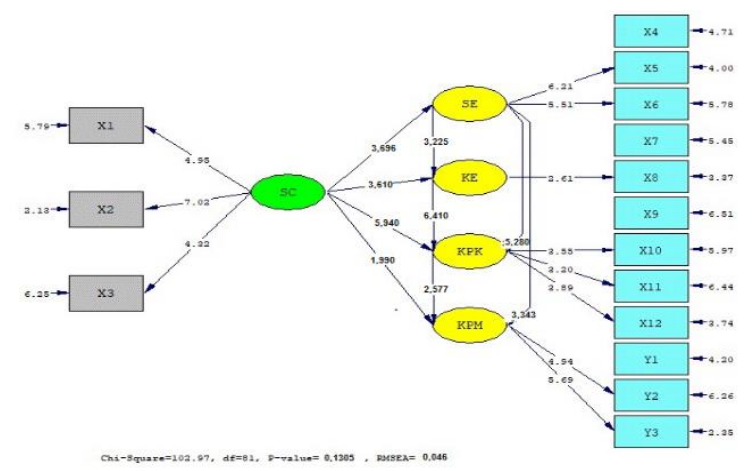

Figure 1. T-Value Basic Model

Based on Figure 1, and the calculation of the complete path coefficient, it is found that the coefficient of each path is significant. This is shown from the count of the efficiency of the road, namely $\rho y 1=0.057$ for the direct effect of $\mathrm{X} 1$ on $\mathrm{Y} ; \rho \mathrm{y} 2=0.260$ for the direct effect of $\mathrm{X} 2$ on $\mathrm{Y}$; $\rho y 4=0.102$ for the direct effect of X4 on Y; $\rho 41$ $=0.266$ for the direct effect of X1 on X4; $442=$ 0.262 for the direct effect of X2 on X4; $443=$ 0.371 for the direct effect of $\mathrm{X} 3$ on $\mathrm{X} 4 ; \rho 31=$ 0.267 for the direct effect of $\mathrm{X} 1$ on $\mathrm{X} 3 ; \rho 32=$ 0.216 for the direct effect of $\mathrm{X} 2$ on $\mathrm{X} 3$; and $\rho 21=$ 0.350 for the direct effect of X1 on X2. Thus, there is a significant direct effect of self-confidence on the ability to solve mathematical problems; There is a significant direct effect of self-efficacy on problem solving skills; There is a significant direct effect on the ability to understand mathematical concepts on the ability to solve mathematical problems; There is a significant direct effect of self-confidence on the ability to understand mathematical concepts; There is a significant effect of self-efficacy on the ability to understand concepts; There is a significant direct effect of self-confidence on emotional intelligence; There is a significant direct effect of self-efficacy on emotional intelligence; There is a significant direct effect on emotional intelligence on the ability to understand concepts; and finally there is a significant direct effect of selfconfidence on self-efficacy.

These results support some of the results of previous studies, such as emotional intelligence, have a role in problem solving skills (Biswas \& Ferdausy, 2017). There is a very close relationship between problem solving, self-efficacy, and mental health (Parto, 2011). They claim that selfefficacy and problem solving are direct and indirect predictors of mental health. Assertiveness is mediated in the relationship between selfefficacy and problem solving with mental health. The results of other studies state that men and women regarding their perceptions of selfefficacy show that when designing any type of educational intervention aimed at improving selfefficacy, the sex of an individual must be taken into account (Flores et al., 2014). (Surya et al., 2017) states that increasing the mathematical problem-solving ability of students taught with contextual learning models is higher than students taught with expository learning. Increased selfconfidence of students who are taught with contextual learning models is higher than students who are taught with expository learning. There is an interaction between the learning model with the students 'initial mathematical ability to improve students' mathematical problem-solving abilities. There is an interaction between learning models with students' initial mathematical abilities to increase student self-confidence. The ability to solve mathematical problems makes a strong contribution to the ability to solve everyday problems. Therefore learning through problem solving based on local culture (ethnomathematics)(Wahyu Widada, Herawaty, Andriyani, Marantika, \& Yanti, 2020; Dewi Herawaty, Khrisnawati, Widada, \& Mundana, 2020 ) is worth recommending (Nugroho et al., 2019). It is an attempt to achieve a mature genetic decomposition in solving problems (Wahyu Widada, 2017; W Widada, 2016). Thus, we believe that the ability to solve mathematical problems is strongly influenced by other variables, namely self-confidence, self-efficacy, emotional intelligence, and the ability to understand concepts.

\section{CONCLUSION}

Problem solving ability is one of the abilities students must have in learning mathematics. The results of this study concluded that the variables of self-confidence, self-efficacy, emotional intelligence, and the ability to understand concepts have a direct positive effect on the ability to solve mathematical problems. Thus, teachers and developers of mathematics learning must involve explicitly and implementatively those variables in the implementation of learning. 


\section{REFERENCES}

Akinmola, E. A. (2014). Developing Mathematical Problem Solving Ability: a Panacea for a Sustainable Development in the 21 St Century By Science and Technical Education Department ,. International Journal of Education and Researc, 2(2), 1$8 . \quad$ Retrieved from http://www.ijern.com/journal/February2014/28.pdf

Amri, S., \& Widada, W. (2019). The Role of selfefficacy and mathematics ability in the problem solving mathematics. Advances in Social Science, Education and Humanities Research, Volume 295, 295(ICETeP 2018), 70-73.

Biswas, M., \& Ferdausy, S. (2017). Role of Emotional Intelligence in Solving Problems in the Private Commercial Banks of Bangladesh. The Comilla University Journal of Business Studies, 4(1), 51-66.

Flores, F. J., Mayorga-Vega, D., Blanco, J. R., \& Blanco, H. (2014). Perceived Self-Efficacy in Problem Solving and Scientific Communication in University Students. A Gender Study. Psychology, 05(05), 358364.

https://doi.org/10.4236/psych.2014.55046

Herawaty, D., Widada, W., Novita, T., Waroka, L., \& Lubis, A. N. M. T. (2018). Students' metacognition on mathematical problem solving through ethnomathematics in Rejang Lebong, Indonesia. Journal of Physics: Conference Series, 1088. https://doi.org/10.1088/17426596/1088/1/012089

Herawaty, Dewi, Khrisnawati, D., Widada, W., \& Mundana, P. (2020). The cognitive process of students in understanding the parallels axiom through ethnomathematics learning. IOP Conf. Series: Journal of Physics: Conf. Series $\quad 1470 \quad$ (2020) 012077 Doi:10.1088/1742-6596/1470/1/012077, 1470, 1-8. https://doi.org/10.1088/17426596/1470/1/012077

Herawaty, Dewi, Widada, W., Adhitya, A., Sari,
R. D. W., \& Novianita, L. (2020). Students ' ability to simplify the concept of function through realistic mathematics learning with the ethnomathematics approach. IOP Conf. Series: Journal of Physics: Conf. Series 1470 (2020) 012031 Doi:10.1088/1742$6596 / 1470 / 1 / 012031, \quad 1470, \quad 1-8$. https://doi.org/10.1088/17426596/1470/1/012031

Herawaty, Dewi, Widada, W., Handayani, S., Febrianti, R., \& Abdurrobbil, F. D. (2020). Students, obstacles in understanding the properties of the closed sets in terms of the APOS theory. IOP Conf. Series: Journal of Physics: Conf. Series 1470 (2020) 012068 Doi:10.1088/1742-6596/1470/1/012068, 1470, 1-7. https://doi.org/10.1088/17426596/1470/1/012068

Herawaty, Dewi, Widada, W., Herdian, F., \& Nugroho, K. U. Z. (2020). The cognitive process of extended trans students in understanding the real number system. IOP Conf. Series: Journal of Physics: Conf. Series $\quad 1470 \quad$ (2020) 012070 Doi:10.1088/1742-6596/1470/1/012070, 1470, 1-6. https://doi.org/10.1088/17426596/1470/1/012070

Mataka, L. M., Cobern, W. W., Grunert, M. L., Mutambuki, J., \& Akom, G. (2014). The Effect of Using an Explicit General Problem Solving Teaching Approach on Elementary Pre-Service Teachers' Ability to Solve Heat Transfer Problems. International Journal of Education in Mathematics, Science and Technology, 2(3). https://doi.org/10.18404/ijemst.34169

Nugroho, K. U. Z., Widada, W., \& Herawaty, D. (2019). The Ability To Solve Mathematical Problems Through Youtube Based Ethnomathematics Learning. International Journal of Scientific \& Technology Research, 8(10), 1232-1237.

Parto, M. (2011). Problem solving, self-efficacy, and mental health in adolescents: Assessing the mediating role of assertiveness. Procedia - Social and Behavioral Sciences, 30, 644648. 
https://doi.org/10.1016/j.sbspro.2011.10.12 5

Peranginangina, S. A., \& Surya, E. (2017). An Analysis of Students' Mathematics Problem Solving Ability in VII Grade at International Journal of Sciences: An Analysis of Students ' Mathematics Problem Solving Ability in VII Grade at SMP Negeri 4 Pancurbatu. International Journal of Sciences: Basic and Applied Research (IJSBAR), 33(2), 57-67.

Surya, E., Putri, F. A., \& Mukhtar. (2017). Improving mathematical problem-solving ability and self-confidence of high school students through contextual learning model. Journal on Mathematics Education, 8(1), 85-94.

https://doi.org/10.22342/jme.8.1.3324.8594

Widada, W., Herawaty, D., \& Lubis, A. N. M. T. (2018). Realistic mathematics learning based on the ethnomathematics in Bengkulu to improve students' cognitive level. Journal of Physics: Conference Series, 1088. https://doi.org/10.1088/17426596/1088/1/012028

Widada, W. (2016). Sintaks Model Pembelajaran Matematika Berdasarkan Perkembangan Kognitif Peserta Didik. Jurnal Pendidikan Matematika Raflesia, 1(2), 163-172.
Widada, Wahyu. (2017). Beberapa Dekomposisi Genetik Siswa dalam Memahami Matematika. Jurnal Pendidikan Matematika Raflesia, 1(1), 44-54.

Widada, Wahyu, \& Herawaty, D. (2017). Dekomposisi Genetik tentang Hambatan Mahasiswa dalam Menerapkan Sifat-sifat Turunan. Jurnal Didaktik Matematika, 4(2), 136-151.

https://doi.org/10.24815/jdm.v4i2.9216

Widada, Wahyu, Herawaty, D., Andriyani, D. S., Marantika, R., \& Yanti, I. D. (2020). The thinking process of students in understanding the concept of graphs during ethnomathematics learning. IOP Conf. Series: Journal of Physics: Conf. Series 1470 (2020) 012072 Doi:10.1088/17426596/1470/1/012072, 1470, 1-8. https://doi.org/10.1088/17426596/1470/1/012072

Wismath, S., Orr, D., Zhong, M., Wismath, S., \& Program, L. E. (2014). Student Perception of Problem Solving Skills Authors ' Contact Information Key Words: Transformative Dialogues: Teaching \& Learning Journal, 7(3), 1-17. 